\title{
Nathalie Ferrand, Livres vus, livres lus: une traversée du roman illustré des Lumières
}

\section{Regina Bochenek-Franczakowa}

\section{(2) OpenEdition}

1 Journals

\section{Édition électronique}

URL : http://journals.openedition.org/studifrancesi/6630

DOI : 10.4000/studifrancesi.6630

ISSN : 2427-5856

Éditeur

Rosenberg \& Sellier

\section{Édition imprimée}

Date de publication : 1 septembre 2010

Pagination : 365

ISSN : 0039-2944

\section{Référence électronique}

Regina Bochenek-Franczakowa, « Nathalie Ferrand, Livres vus, livres lus: une traversée du roman illustré des Lumières », Studi Francesi [En ligne], 161 (LIV | II) | 2010, mis en ligne le 30 novembre 2015, consulté le 09 janvier 2021. URL : http://journals.openedition.org/studifrancesi/6630 ; DOI : https:// doi.org/10.4000/studifrancesi.6630

Ce document a été généré automatiquement le 9 janvier 2021.

\section{(c)}

Studi Francesi è distribuita con Licenza Creative Commons Attribuzione - Non commerciale - Non opere derivate 4.0 Internazionale. 


\title{
Nathalie Ferrand, Livres vus, livres lus: une traversée du roman illustré des Lumières
}

\author{
Regina Bochenek-Franczakowa
}

\section{RÉFÉRENCE}

NATHALIE FERRAND, Livres vus, livres lus: une traversée du roman illustré des Lumières, Oxford, Voltaire Foundation, 2009 (SVEC 2009:03), pp. 282.

1 Après son ouvrage sur le motif de la lecture dans le roman du XviII ${ }^{\mathrm{e}}$ siècle, Nathalie Ferrand s'est proposé d'examiner la présence du livre, de la bibliothèque et de l'acte de lire dans les estampes qui accompagnent les éditions de romans des Lumières. L'auteur a dépouillé près de 170 éditions illustrées dont elle a choisi 112 planches pour son anthologie. De Fénelon à Mme de Genlis, tout le siècle est pris en considération, ce qui lui a permis de montrer l'évolution des styles et des sujets. La réflexion porte sur le rapport entre le texte et l'image, ce que le livre et la bibliothèque en tant qu'objets représentés sur la gravure rendent saillant et significatif. Consciente des écarts inévitables entre le texte littéraire et les arts plastiques, l'auteur a choisi de considérer l'image pour elle-même, afin de tenter, comme elle avoue, «un exercice d'interprétation du roman à travers son triple dispositif textuel, visuel et matériel: une iconologie du roman comme objet d'art» (p. 42). L'anthologie est divisée en cinq sections: «Rares lecteurs», «La place du livre religieux», "Des bibliothèques en perspective», «Les femmes parmi leurs livres», «Livres fabriqués, exposés, imaginés».

Plusieurs séquences d'images sont examinées, où l'on trouve la combinaison des trois motifs choisis: le livre, la lecture, la bibliothèque. L'auteur a observé la raréfaction du motif de la lecture dans les estampes, contrairement à la présence importante de celleci dans les romans: l'acte de lire, trop statique et introspectif, n'intéresse pas les illustrateurs qui préfèrent représenter le personnage sur le fond d'une bibliothèque, ce 
qui permet des effets de profondeur et de perspective. Le corps lisant est fréquent dans la gravure accompagnant les romans libertins ou pornographiques, dans une scène qui marque le désir violent: c'est le corps féminin qui s'offre ici au regard de l'observateur masculin «voyeur». Fait curieux, cependant: si dans les romans la lecture est féminisée, sur l'estampe, c'est le personnage masculin qui domine, lisant ou tenant un livre. Un autre phénomène remarqué est la disparition de la symbolique du livre représenté sur l'image: c'est que, constate l'auteur, l'illustration est là «pour dialoguer et se confronter avec [le texte] afin de faire durer les pouvoirs du langage et de l'imaginaire» (p. 44).

3 L'anthologie de Nathalie Ferrand propose une «traversée» à la fois variée et cohérente, où les effets «d'échos et de sens», joints à ceux d'intericonicité tissent un réseau intéressant d'interprétations riches en aperçus éclairants et originaux.

\section{AUTEURS}

REGINA BOCHENEK-FRANCZAKOWA

fr 